Check for updates

The BMJ

Cite this as: BMJ2020;370:m2897 http://dx.doi.org/10.1136/bmj.m2897 Published: 20 July 2020

\section{Covid-19: Leicester's lockdown to ease this weekend as infection rates fall}

\section{Elisabeth Mahase}

Some lockdown restrictions are to be eased in Leicester two weeks after local measures were put in place, ${ }^{1}$ the health secretary Matt Hancock has announced.

Speaking in the House of Commons on 16 July Hancock said a decline in the seven day infection rate meant that restrictions on schools and early years childcare would be eased, while non-essential shops could reopen from 24 July. But he said the local government has been given the power to reclose shops where necessary.

"Other restrictions like those for travel and only having social gatherings of up to six people will remain in force. National measures introduced on 4 July, like opening the hospitality sector, will also not yet apply," he said.

Hancock also announced changes to the local lockdown boundary, with restrictions now only applying to the city itself and the Oadby and Wigston area of Leicestershire. According to the health secretary, the seven day infection rate has been brought down from 135 cases per 100 ooo people when the local lockdown was announced, to 119 cases per 100 ooo. Meanwhile, the percentage of people who have tested positive is now $4.8 \%$.

"These are positive indicators, especially in light of the huge increase in testing in the local area. But they remain well above the national average and the average of the surrounding areas," he said. The restrictions will be reviewed again in two weeks.

The health secretary also used his time in parliament to inform MPs of problems with some of the covid-19 swab tests supplied by diagnostics company Randox.

Hancock said, "We've identified some swabs that are not up to the high standard we expect and will be carrying out further testing of this batch as a proposed precautionary measure. Clinical advice is that there is no evidence of any harm, the test results are not affected. While we investigate further, we're requesting that the use of Randox swab test kits are paused, in all settings, until further notice.”

When asked for more details on the problem, he said that "upon investigation, CE certification was not forthcoming. Physical checks were done and we found that the swabs weren't up to the standards that we expect.”

He added that there is still "full access to testing because we have plenty of other test kits available."

Randox is thought to be responsible for around $17 \%$ of the total tests carried out in the UK. The company was given the $€ 133 \mathrm{~m}\left(€_{146 \mathrm{~m}}\right.$ \$167m) contract to produce testing kits for England, Wales, and Northern Ireland by the government in March.

Responding to the statement in the Commons, shadow health secretary Jon Ashworth, Labour Party MP for South Leicester, criticised Hancock for outsourcing contracts to private companies rather than funding the public systems already in place.

He said, “He’s throwing good money after bad, why doesn't he invest in public health services, primary care, and local health teams to do this testing?"

Mahase E. Covid-19: Leicester placed under lockdown after spike in cases and hospital admissions. BMJ2020;369:m2635. doi: 10.1136/bmj.m2635 pmid: 32605928

This article is made freely available for use in accordance with BMJ's website terms and conditions for the duration of the covid-19 pandemic or until otherwise determined by BMJ. You may use, download and print the article for any lawful, non-commercial purpose (including text and data mining) provided that all copyright notices and trade marks are retained. 